\title{
Building effective agbiotech partnerships founded on trust: a summary of the challenges and practices in sub-Saharan Africa
}

\author{
Obidimma C Ezezika $a^{1,2,3}$
}

The potential for improving the efficiency and success of partnerships in agricultural biotechnology is contingent on the presence of trust. As Stephen Covey (2006) asserts in his book The Speed of Trust, trust is the basis of the new global economy and is an essential element of any successful organization [1]. The presence of trust is particularly important in public-private partnerships (PPPs), in which partners with varied interests, goals, and operating principles embark on complex tasks within innovative ventures.

Even more crucial is the role of trust in the success of agbiotech initiatives led by PPPs. This is cited throughout the literature on trust and has been confirmed by numerous agricultural stakeholders who participated in our case studies of agbiotech PPPs in Africa [2-9]. Stakeholders linked project successes with the establishment and maintenance of trust throughout the duration of their respective partnerships. When trust was broken or nonexistent in the partnerships, stakeholders reported an evident negative impact on the partnerships. In several cases, stakeholders cited instances in which the erosion of trust led to severed ties among stakeholders of the project or to slow progression of certain phases of the projects, such as product development or biosafety approval.

From meeting with Bacillus thuringiensis (Bt) maize farmers in South Africa and Egypt to chatting with Bt cotton farmers in Burkina Faso and regulators in Tanzania, several key lessons were derived on trust building for improving success in innovative PPP projects in subSaharan Africa. This was accomplished through direct observations, face-to-face interviews, and review of project documents.

Public suspicion of the private sector and genetically modified (GM) technology was cited as a major barrier to building trust between the PPP projects and the

'Sandra Rotman Centre, University Health Network and University of

Toronto, Toronto, Ontario, Canada

Full list of author information is available at the end of the article public, and, occasionally, between the PPP projects and the regulatory bodies of the government. This challenge was brought up by stakeholders in several case studies, including those conducted in Burkina Faso [3], Nigeria [6] and Kenya [7]. Stakeholders mentioned that the public questions the motive behind the private sector's involvement in agbiotech projects in Africa; the public suspects that the private sector is being driven solely by the profit motive. This challenge, posed by public suspicion, to establishing trust in the partnership proved more pervasive and difficult to overcome in projects that focused on the cultivation of crops for staple foods for human consumption-such as the Insect Resistance Maize for Africa (IRMA) - than in projects focused on non-food crops, such as the Bt cotton project in Burkina Faso.

In some countries such as Burkina Faso and Uganda, the lack of sufficient community engagement during the research, development, and implementation phases of the projects created challenges to building trust in the partnerships $[3,8]$. Without community engagement, farmers and community members were often left uninformed-and thus, concerned-about the GM crop technology. For example, in Burkina Faso a significant challenge arose when researchers failed to communicate with journalists, who are the conduit through which information reaches the public. Instead of sharing information about the technology, researchers were referring journalists up the bureaucratic ladder [3]. Such disconnect between researchers' knowledge of the technology and the uninformed community fostered public distrust in the technology and the research and development $(\mathrm{R} \& \mathrm{D})$ process. This posed a significant challenge to the projects' further outreach efforts to appeasing a skeptical and apprehensive public.

Another challenge to trust building was the slow and often inconsistent regulatory processes through which project partners would have to navigate in order to receive approval for trials and commercialization. This challenge 
was observed in the Virus Resistant Cassava for Africa (VIRCA) project [8], the Bt cowpea project in Nigeria [6], and the Bt cotton project in East Africa [9]. Slow regulatory processes were considered by stakeholders to be barriers to building trust, as the private sector had difficulties anticipating the needs of the regulatory bodies and understanding the regulatory processes within the public domain that their applications underwent.

Engaging the public and the project partners through 'farm walks' was considered an effective practice for building trust. Farm walks consist of hosting media representatives, farmers, politicians and other members of the community to allow them to explore the in-field activities of the PPPs and see the crops firsthand. They were reported as particularly effective in facilitating opportunities for participants to directly observe and compare the performance of conventional crops with that of GM crops $[4,5]$. This was found to build participants' trust in the technology. The success of the farm walks was observed in a number of projects, including: IRMA in Kenya [7], Bt maize in Egypt [5], Bt cotton in Burkina Faso [3], and Bt maize in South Africa [4].

In addition, community education workshops were held in Burkina Faso, Tanzania, and South Africa to communicate facts about agricultural biotechnology to the public. When conducting these workshops, acknowledgement of the different literacy levels among, and different languages spoken by, all members of the community was important for effectively communicating information about the technology. These workshops, combined with farm walks and other demonstrations of project activities, served to build trust between members of the community and the private sector, as well as between farmers and the technology. These case studies show that holding community engagement programs at the field level throughout the research and development of the biotech crops are essential for building trust in the partnerships. These programs, by directly engaging the end users, can serve to boost transparency and eliminate suspicions.

The importance of clear communication among stakeholders was identified by interviewees across almost all of the case studies. This was explained as particularly important in terms of specifying the roles and responsibilities of partners and clearly outlining a project's priorities. Detailed agreements and clarifying partners' roles and responsibilities, for example, were considered necessary for dispelling perceptions of inequality among partners in the VIRCA and IRMA partnerships. Full disclosure of information was therefore regarded as a highly important practice that served to build transparency, and, in turn, trust among the project partners.

The need for building and sustaining trust does not stop after the crops have been commercialized; it is a continuous process that depends on the ability of both the farmers and seed companies to promote, implement and monitor compliance to proper agronomic practices. Good agronomic practices, for example, include the distancing of GM and non-GM crops physically and temporally and planting refuge areas in order to prevent insect resistance to transgenic crops. However, these practices are not always implemented and monitored correctly, as learned from the Bt maize project in South Africa [4]. On the one hand, not all seed providers, in their interactions with farmers, promote the importance of buying conventional seed for planting the refuge areas; some farmers are therefore left unaware of such a need. On the other hand, some farmers who are aware of the need for planting refuge areas choose to neglect it due to concerns about being unable to maximize yield and profit.

Implementing good agronomic practices is a major trust-building practice that has been shown to improve relations among farmers, seed providers, and the private sector $[3,4]$. Planting the refuge areas also ensures sustained effectiveness of the GM technologies, thus improving the public's ability to build trust in the technology and their providers. Farmers and private sector representatives seeking to build trust to foster the success of their projects can all benefit from following proper agronomic practices.

The presence or absence of trust among partners working in an agricultural PPP in Africa, as well as between the PPP and the community, can determine the effectiveness and sustainability of innovations implemented by the partnership. The lessons from these case studies have provided insight on how to build and maintain trust in PPPs for successfully implementing programs that foster innovation.

\section{Acknowledgements}

This article has been published as part of Agriculture \& Food Security Volume 1 Supplement 1, 2012: Fostering innovation through building trust: lessons from agricultural biotechnology partnerships in Africa. The full contents of the supplement are available online at http://www.agricultureandfoodsecurity. com/supplements/1/S1. Publication of this supplement was funded by the Sandra Rotman Centre at the University Health Network and the University of Toronto. The supplement was devised by the Sandra Rotman Centre.

\section{Author details}

'Sandra Rotman Centre, University Health Network and University of Toronto, Toronto, Ontario, Canada. ${ }^{2}$ African Centre for Innovation and Leadership Development, Federal Capital Territory, Abuja, Nigeria. ${ }^{3}$ Dalla Lana School of Public Health, University of Toronto, Toronto, Canada.

\section{Competing interests}

The author declares that they have no competing interests.

Published: 1 November 2012

\section{References}

1. Covey S: The Speed of Trust: The One Thing That Changes Everything. New York: Free Press; 2006. 
2. Ezezika OC, Oh J: What is trust? Perspectives from farmers and other experts in the field of agriculture. Agriculture \& Food Security 2012, 1(Suppl 1):S1.

3. Ezezika OC, Barber K, Daar AS: The value of trust in biotech crop development: a case study of Bt cotton in Burkina Faso. Agriculture \& Food Security 2012, 1(Suppl 1):S2.

4. Ezezika OC, Lennox R, Daar AS: Strategies for building trust with farmers: the case of Bt maize in South Africa. Agriculture \& Food Security 2012, 1(Suppl 1):S3.

5. Ezezika OC, Daar AS: Building trust in biotechnology crops in light of the Arab Spring: a case study of Bt maize in Egypt. Agriculture \& Food Security 2012, 1(Suppl 1):S4.

6. Ezezika OC, Daar AS: Overcoming barriers to trust in agricultural biotechnology projects: a case study of Bt cowpea in Nigeria. Agriculture \& Food Security 2012, 1(Suppl 1):S5.

7. Mabeya J, Ezezika OC: Unfulfilled farmer expectations: the case of the Insect Resistant Maize for Africa (IRMA) project in Kenya. Agriculture \& Food Security 2012, 1(Suppl 1):S6.

8. Ezezika OC, Mabeya J, Daar AS: Building effective partnerships: the role of trust in the Virs Resistant Cassava for Africa project. Agriculture \& Food Security 2012, 1(Suppl 1):S7.

9. Ezezika OC, Mabeya J, Daar AS: Harmonized biosafety regulations are key to trust building in regional agbiotech partnerships: the case of the Bt cotton project in East Africa. Agriculture \& Food Security 2012, 1(Suppl 1): 58.

doi:10.1186/2048-7010-1-S1-S9

Cite this article as: Ezezika: Building effective agbiotech partnerships founded on trust: a summary of the challenges and practices in subSaharan Africa. Agriculture \& Food Security 2012 1(Suppl 1):S9.

\section{Submit your next manuscript to BioMed Central} and take full advantage of:

- Convenient online submission

- Thorough peer review

- No space constraints or color figure charges

- Immediate publication on acceptance

- Inclusion in PubMed, CAS, Scopus and Google Scholar

- Research which is freely available for redistribution

Submit your manuscript at www.biomedcentral.com/submit
Biomed Central 